This item was submitted to Loughborough's Institutional Repository (https://dspace.lboro.ac.uk/) by the author and is made available under the following Creative Commons Licence conditions.

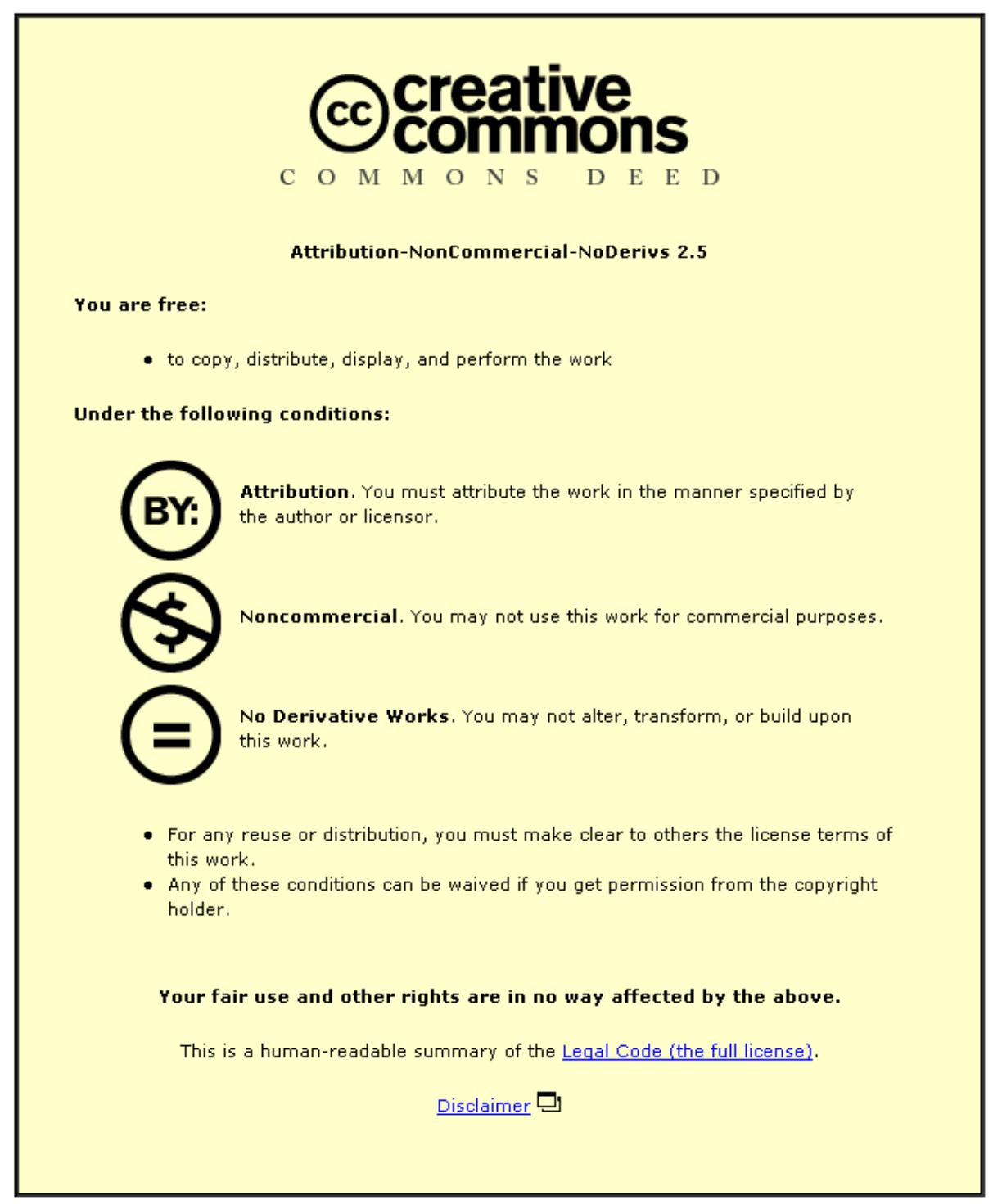

For the full text of this licence, please go to: http://creativecommons.org/licenses/by-nc-nd/2.5/ 


\title{
Women in Management and Leadership in the Olympic Movement in Muslim Majority Countries: an empirical evaluation of Huntington's Clash of Civilisations Typology \\ Shushu Chen and lan Henry ${ }^{1}$
}

\begin{abstract}
This paper seeks to evaluate whether there are differences between Samuel Huntington's 'civilisational groups' of countries in terms of women's leadership of Olympic organisations. The paper draws on two questionnaire surveys which evaluate the electoral practices and outcomes of Olympic bodies (i.e. National Olympic Committees and International Federations) relating to gender equity and governance, with a specific intention to compare the role of women in the leadership of such bodies between Islamic societies and non-Islamic contexts. The vehicle for analysing the data employs Huntington's well-known but controversial civilisational typology which identifies nine major cultural civilisational groups (including Western and Islamic states). This allows the authors to explore the extent to which differences exist between Western and Islamic societies and others, with regard to women's roles in leadership and governance of Olympic bodies. Differences between Muslim, and other religious groupings on the one hand and secular liberal democratic groupings on the other, are often assumed to reflect the distinction between tradition and modernity, and sport is seen in the literature in large part as a product of modernity. However results of the statistical analysis of women's roles in senior positions in NOCs in particular, do not reflect Western 'superiority' in terms of women's representation. The paper thus casts doubt on the appropriateness of considering the Islamic norm as traditional, and the Western norm as modern.
\end{abstract}

Keywords: Women's leadership, gender equity, Islamic, Western, Clash of civilisations, Olympic movement

Shushu Chen is

Ian Henry is Professor, and Director of the Centre for Olympic Studies and Research at Loughborough University. He has published widely in the field of sport policy and politic, comparative policy analysis, and sport policy evaluation.

\section{Introduction}

The focus of much which has been written about gender equity in Olympic sport has focused on participation, and in some significant respects progress has been made. Predictions immediately prior to the 2012 Olympic Games suggested that in terms of numbers of men and women participating parity was being approached (though 1114 more men than women were participants) [1] and there was parity also in terms of the numbers of sports and events available to men and women.[2] Given the universal pretensions of the Olympic movement there has within this literature also been a focus on cultural differences between and within societies in terms of women's participation, much of which is written from

\footnotetext{
${ }^{1}$ Shushu Chen and Ian Henry are from the Centre for Olympic Studies, Loughborough University. Correspondence to: s.chen@Iboro.ac.uk Address: Loughborough University, Loughborough, LE11 3TU. Telephone: +44 (0) 1509226362.
} 
a western perspective, particularly in relation to the issue of Muslim women's participation in sport, and the touchtone issue of women and the wearing of the hijab has drawn considerable attention. [3] Progress in terms of fostering participation among women across different cultures has been variable but the 2012 Games will be the first in which all participating National Olympic Committees (NOCs, including Saudi Arabia, Qatar, and Brunei) will have one or more female participants. [4]

Since the adoption by the IOC of minimum targets for women to take up executive positions in NOCs and International Federations (IFs) there has been growing concern addressed to the issue of women and leadership or management of Olympic sports organisations, and within this context on equity in relation to Muslim women and/or women from the Middle East. The issue is one in which the Olympic movement has sought to tread a fine line between the discourses of universalism, and respect for cultural specificity.

Within the context of these policy concerns the aim of this paper is to evaluate the roles played by women in Muslim majority states in the contemporary governance of Olympic bodies. We evaluate their presence in roles predominantly as NOC executive board senior officers and members. To address this focus on gender and geo-political equity we draw on data from two studies commissioned by the IOC from Loughborough University relating to women and leadership in the Olympic movement .These two studies had separate but related goals, and were linked to the IOC's efforts to tackle gender equity in the leadership and management of the Olympic movement. The first was designed to assess the impact of the IOC's introduction in 1997 of minimum targets for membership of NOC and IF executive committees. The second study was designed to address the problems associated with the recruitment, election, and postelection experiences of women in senior positions (presidents, secretary generals, and treasurers) in these bodies. The data generated for these studies from questionnaires addressed to all NOCs (study1) and all NOCs and IFs (study 2) identifies responses to the IOC minimum targets, in terms of strategies adopted and outcomes achieved, gender make-up of Executive Committees, electoral practices, female representation as candidates and elected senior officials. Together with interviews with male and female post-holders (presidents and secretary generals) from all five continents, these provide us with a basis against which to evaluate differences within and between various geopolitical groups in terms of their engagement with the Olympic movement. Consideration and explication of such differences constitute a primary aim of this article.

As background to our concerns, we note that the Olympic movement has its origins in Western Europe and continues to be dominated in terms of its membership by individuals from this region. The ratio of the percentage of members of the IOC from the different continents to the percentage of the world population size for each continent shows that (with the exception of Oceania which has a relatively small population and only three IOC members), Europe is significantly over-represented compared to the other continents (see figure 1.) 


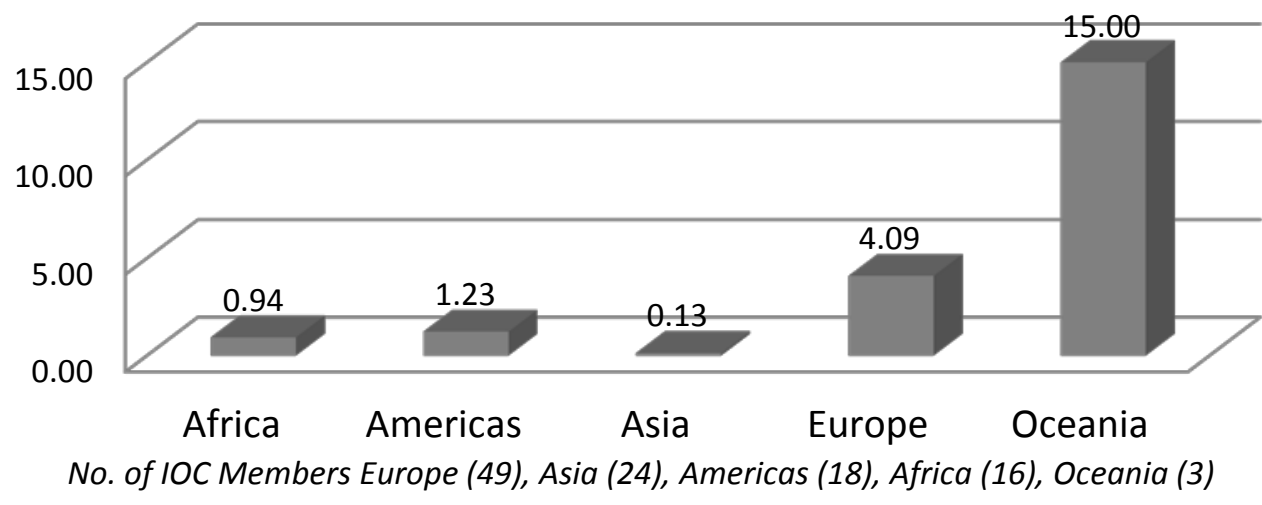

\section{Gender and cultural diversity in Muslim communities and nation states}

Although in this article we will be looking to the statistical aggregation of data about women in Muslim majority countries, we need to acknowledge that these countries are generally Muslim majority (and therefore also incorporate women from different politico religious groupings both within and outwith Islam) and that the treatment and experience of women varies in significant ways between countries banded together in this category. The collection by Haddad and Esposito, for example, compares and contrasts the experience of women in Egypt, Jordan, Pakistan, Oman, Kuwait, and Jordan, while the account by Fernea undertakes a similar task from a more journalistic perspective highlighting significant differences in work, education, legal rights, and cultural practices, and it is important therefore to distinguish differences in religiosity ('local' interpretations of social and religious practices and requirements) from core religious beliefs which may be shared by all Muslim groups. The point to be made is one which Malik expresses in relation to Muslims in Britain, but which is applicable to a broader set of Muslim societies:

'Islam ..... is far from being a monolith; it is a matrix of the national, ethnic, doctrinal and economic diversities where variables like age, education, class, ethno-regional background and attitudes towards religion and the non-Muslim communities determine an entire plethora of variegated responses.'

In addition to the problem of generalising about women's experience within and between societies the diversity among feminists in Muslim majority societies also requires acknowledgement. Karam for example distinguishes between Islamic, Muslim, and secular feminism in modern Egypt, highlighting the diverse nature of women's views (and actions) in relation to gender equity within that society. Even in a society which is regarded as among the most conservative, such as Iran, Afshar draws a similar picture of diversity among feminist views. It is important to bear these matters in mind to guard against the 'othering' of non-western women as perceived from western perspectives

Perhaps the most prominent western construction of the Eastern 'other' in the post-Cold War era has been provided by Samuel Huntington's civilisational analysis in which he argued that in place of the bipolar Cold War system based on political ideology, a multi-polar system of international relations has emerged in the last quarter of the twentieth century, of which cultural, rather than political, ideologies are the defining feature. Huntington identifies nine civilisational groups (Western, Latin American, African, Islamic, Sinic, Hindu, Orthodox, Buddhist, and Japanese) and argues that at base these cultures embrace incompatible 
values with the clear implication that if the West wishes to defend its core liberal democratic values it may have to use force ultimately to do so.

Huntington's clash of civilisations thesis has been attacked on a number of counts, but principally because it is argued that he over-emphasised the separation of civilisational cultures portraying them as cultural 'silos' whereas the similarities between groups across cultures are far greater - for example between Muslim, Christian, Jewish, and secular feminists than they are between feminists and conservative groups within each of these respective cultures. In addition the thesis is regarded as dangerous since its thinking has informed neo-conservative stances supporting war against groups from other cultures, and principally of course the Muslim 'other'. A major objective of our analysis in this article is the evaluation of the extent to which cultural differences between countries identified in Huntington's civilisational groupings are manifest in the data relating to women's involvement in leadership roles in NOCs in 'Muslim majority countries' (which Huntington terms 'Islamic' countries). Related to this question lies the core problematic of whether promotion of Olympic 'universals' such as gender equity for all, is consistent with (respect for) cultural specificities.

\section{Methodology}

Thus the core research question which this paper is addressing is whether there are significant differences in the electoral practices and outcomes of Olympic bodies (specifically NOCs) in the Muslim majority countries, and other Huntington civilisational groups of countries? In addressing this research question the paper draws on data from the two IOC commissioned studies cited earlier. These two studies had different but related aims and methods which were as follows.

- The 2004 study aimed to evaluate the processes of recruitment of women to decision-making structures, their career paths into Olympic leadership, their impact on the activities of the organizations themselves, and the nature of training and support required by both the women members and the sports organizations to ensure that the benefits of wider involvement in decisionmaking by women are realised.

- The 2010 study aimed to identify the nature of electoral practices and processes within NOCs and IFs for election to executive committees or boards, and in particular to the most senior roles (Presidents / Secretary Generals) within those bodies. It further aimed to identify the nature of electoral experiences of women with a view to clarifying key success factors in the election of women to senior positions in NOC executives.

The methods adopted in the two studies were as follows.

- In the 2004 study two questionnaires were distributed: the first to all identified female members of NOC executives, and the second to all NOC Secretary Generals. In addition in-depth interviews were undertaken with one in eight of all female members of NOC executives, $(n=30)$, and one in eight of all Sec Gen's ( $n=25$ ).

- In the 2010 study questionnaires were distributed to all NOCs and IFs and in-depth interviews were undertaken with 36 female presidents, secretary-general's, or other significant post holders in NOCs / IFs.

The response rates for the four surveys are provided in table 1. In the context of our subsequent discussion it should be noted that while the overall response rate for NOCs was close to $50 \%$ for all three NOC-related 
questionnaires, the response rate for Asia was significantly lower from $24 \%$ to $39 \%$ across the three questionnaires.

Table 1. Response rates for the four questionnaires distributed in the Henry et al. (2004) and Henry \& Robinson (2010) studies

\begin{tabular}{lrrrr}
\hline & $\begin{array}{r}\mathbf{2 0 0 4} \\
\text { Questionnaire } \\
\text { survey to Female } \\
\text { members of NOC } \\
\text { Execs. }\end{array}$ & $\begin{array}{r}\mathbf{2 0 0 4} \\
\text { Questionnaire } \\
\text { survey to NOCs } \\
\text { (Secretary } \\
\text { Generals). }\end{array}$ & $\begin{array}{r}\mathbf{2 0 1 0} \\
\text { Questionnaire } \\
\text { survey to NOCs } \\
\text { concerning }\end{array}$ & $\begin{array}{r}\mathbf{2 0 1 0} \\
\text { electoral practices }\end{array}$ \\
\hline Questionnaire \\
Africa & & $\begin{array}{r}\text { Summer / } \\
\text { Recognised) IFs } \\
\text { concerning }\end{array}$ \\
Americas & $37(51 \%)$ & $25(47 \%)$ & $24(45 \%)$ & \\
Asia & $26(42 \%)$ & $17(42 \%)$ & $20(48 \%)$ & \\
Europe & $19(29 \%)$ & $10(24 \%)$ & $17(39 \%)$ & \\
Oceania & $57(56 \%)$ & $34(71 \%)$ & $37(76 \%)$ & $12(71 \%)$ \\
Total & $7(50 \%)$ & $3(21 \%)$ & $\mathbf{1 1 0 ( 5 4 \% )}$ & $\mathbf{5 0}(\mathbf{7 0 \% )}$ \\
\hline
\end{tabular}

While the data was collected for other purposes they allow us the opportunity to consider what they revealed about Muslim majority countries in comparison with other cultural groupings of countries. We have specifically revisited the 2010 data to establish whether there are significant differences between Huntington's civilisational groups in respect of electoral practices and outcomes relating to women on NOCs.

In seeking to make a comparison of the role of women in the leadership of the Olympic bodies between Islamic and the other Huntington groups (i.e. Western, Orthodox, African, Latin American, Sinic, Hindu, Buddhist, and Japanese), we should note that because of the small numbers in some Huntington groupings (Japan for example is one category or civilisational group on its own) and / or lower response rates we have grouped together the following Huntington groups, Sinic $(n=1)$, Hindu $(n=2)$, Buddhist $(n=2)$, and Japanese $(n=1)$, into a combined category of 'Asian other' to allow some statistical treatment of differences. In the analysis which follows differences which exist between the ('modified') Huntington cultural groups, are assessed in terms of their statistical significance by reference to differences in means for parametric statistics (evaluated largely by analysis of variance) and for non-parametric data by reference to Chisquare test of independence.

While the response rate for the 2010 survey was $53.7 \%$, these responses were not evenly spread across all of the six modified Huntington Groups (see Table 2). While response rates for the Western and Orthodox groups were high ( $74 \%$ and $62 \%$ respectively), 'Asian other' is under-represented in the sample with a return rate of $29 \%$, and thus some caution needs to be exercised in relation to this group in particular. 


\begin{tabular}{|c|c|c|c|}
\hline & & FREQUENCY & RESPONSE RATE \\
\hline \multirow{7}{*}{ 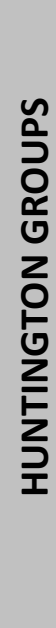 } & Western (58) & 43 & $74 \%$ \\
\hline & Orthodox (13) & 8 & $62 \%$ \\
\hline & Islamic (46) & 20 & $43 \%$ \\
\hline & African (34) & 16 & $47 \%$ \\
\hline & Latin American (34) & 17 & $50 \%$ \\
\hline & Asian Other (21) & 6 & $29 \%$ \\
\hline & Total of NOCs (205) & 110 & $54 \%$ \\
\hline
\end{tabular}

\section{Data analysis}

In order to structure our evaluation of the difference between groups we have grouped together dependent variables into six categories as described below. For parametric data the comparison of means between the (amended) Huntington groups is carried out largely employing analysis of variance with planned comparison, and with non-parametric a chi square test of difference is used.

Group 1: Indicators of Female Participation in NOC Elections

- $\%$ of candidates who are female in the most recent election of (a) presidents; (b) secretary general; (c) treasurer; (d) members of Executive Committee.

Group 2: Indicators of Gendered Outcomes of NOC Elections

- Number of women elected to Executive Committees

- \% of those elected to Executive Committees who are women

- Numbers of NOCs with female (a) presidents; (b) secretary generals; (c) treasurers.

Group 3 Indicators of Gendered Outcomes in Mainstream National Politics (data for this variable sourced from )

- \% of Lower House elected who are female

- \% of Upper House who are female

- \% of ministerial positions occupied by women.

Group 4: Professional Roles Played by Women in the NOC

- $\%$ of those in full time professional roles who are women

- $\%$ of those in full time professional roles who are men

Group 5 Indicators of Democratic Health of the NOC Electoral System

- Electoral competition - whether there was more than one candidate standing in the most recent election of (a) presidents; (b) secretary general; (c) treasurer; (d) members of Executive Committee.

Group 6: Existence of a Formal Statement of Gender Equity Policy 
- Whether the NOC has a Women in Sport Commission or equivalent;

- Whether the NOC had adopted a formal policy in relation to gender equity;

- whether the NOC had adopted formal performance measures related to gender equity..

\section{Group 1: Indicators of Female Participation in NOC Elections}

One of the ways in which religious groups in general and Muslim groups in particular are contrasted with others in the contemporary world is by reference to the notions of tradition and modernity. Religious perspectives are seen as reliant on traditional world views and social distinctions, which are pre-modern or even anti-modern (implying a non-rational approach to social, economic and political order). Thus the development of liberal democratic political choices is seen as stemming from a modernist political tradition. The participation of women in political sphere is thus regarded as product of modernity, just as liberal democracy and pluralism are seen as stemming from European Enlightenment thought.

This group of indicators relate to the percentage of female candidates in the last election for the roles of president, secretary general and treasurer within the NOC and for the Executive board. The higher the percentage of female candidates, the less traditional the approach adopted in relation to gender participation in NOC politics. One way analysis of variance with planned comparison of Muslim and other groups was employed but indicate that there are no statistically significant differences between NOCs from majority Muslim countries in respect of these variables. Differences in means are provided in Table 1, and the Islamic group of NOCs has a higher proportion of female candidates than the men for all NOCs for both presidential elections and those of secretary generals, though with a smaller percentage in both of the other categories. Thus there is clearly no evidence to support any description of the Islamic group being lexx engaged in the NOC political system.

Table 3. Female participation in NOC elections by (amended) Huntington groups

\begin{tabular}{lrrrr}
\hline & $\begin{array}{r}\text { \% of female } \\
\text { candidates } \\
\text { for the } \\
\text { Presidency }\end{array}$ & $\begin{array}{r}\text { \% of female } \\
\text { candidates } \\
\text { for post of } \\
\text { Secretary } \\
\text { General }\end{array}$ & $\begin{array}{r}\text { \% of female } \\
\text { candidates for } \\
\text { the post of } \\
\text { Treasurer }\end{array}$ & $\begin{array}{r}\text { \% of candidates for } \\
\text { other Executive } \\
\text { Board posts were } \\
\text { female }\end{array}$ \\
\hline Western & 6.3 & 11.5 & 8.3 & 29.9 \\
Orthodox & 3.6 & 20 & 33.3 & 5.83 \\
Islamic & 9.5 & 16.3 & 2 & 18.09 \\
African & 17.9 & 18.2 & 6.3 & 21.79 \\
Latin & 0 & 6.7 & 3.9 & 26.46 \\
American & & & & 16.67 \\
Asian Other & 0 & 0 & 0 & 23.88 \\
\hline All Nocs & 7.1 & 12.5 & 6.6 & \\
\hline
\end{tabular}


The number of female presidents, secretary generals, and treasurers and the percentage of Executive Committee indicated in Table 3 also shows relatively little variation across the Huntington Groups. Thus although there are relatively few women in the sample from Muslim majority countries in the principal positions of influence in NOCs, low representation of females is certainly not a finding which is limited to the Muslim majority group. Analysis of variance conducted on the percentage and on the number of female members of the Executive Committee in the NOCs indicates that there is not a statistically significant difference between the groups.

Table 4. Indicators of gendered outcomes of elections

\begin{tabular}{|c|c|c|c|c|c|c|}
\hline & Western & Orthodox & Islamic & African & $\begin{array}{r}\text { Latin } \\
\text { American }\end{array}$ & Asian other \\
\hline $\begin{array}{l}\text { No of female } \\
\text { presidents }\end{array}$ & 3 & 0 & 2 & 2 & 0 & 0 \\
\hline $\begin{array}{lll}\% \text { of female } \\
\text { presidents }\end{array}$ & 7 & 0 & 10.5 & 12.5 & 0 & 0 \\
\hline Total of NOCs & 43 & 8 & 19 & 16 & 15 & 5 \\
\hline No of female SG & 6 & 1 & 2 & 3 & 1 & 0 \\
\hline$\%$ of female SG & 16.7 & 14.2 & 11.8 & 20 & 6.7 & 0 \\
\hline Total of NOCs & 36 & 7 & 17 & 15 & 14 & 5 \\
\hline $\begin{array}{ll}\text { No of female } \\
\text { Treasurers }\end{array}$ & 2 & 1 & 1 & 1 & 1 & 0 \\
\hline $\begin{array}{l}\% \quad \text { of female } \\
\text { Treasurers }\end{array}$ & 8 & 25 & 6.3 & 6.7 & 7.8 & 0 \\
\hline Total of NOCs & 25 & 4 & 16 & 15 & 13 & 4 \\
\hline $\begin{array}{l}\text { Mean \% of female } \\
\text { Executive Mmbrs }\end{array}$ & 18.8 & 9.1 & 15.1 & 19.4 & 20.8 & 14.4 \\
\hline $\begin{array}{l}\text { SD \% of female } \\
\text { Executive Mmbrs }\end{array}$ & 12.5 & 5.9 & 10.8 & 7.5 & 11.2 & 14.0 \\
\hline $\begin{array}{l}\text { Mean no. of female } \\
\text { Executive Mmbrs }\end{array}$ & 2.37 & 1.75 & 2.29 & 2.44 & 1.93 & 1.25 \\
\hline $\begin{array}{l}\text { SD of no. of female } \\
\text { Executive Mmbrs }\end{array}$ & 1.705 & .886 & 1.404 & 1.094 & 1.100 & .957 \\
\hline Total of NOCs & 43 & 8 & 18 & 16 & 15 & 4 \\
\hline
\end{tabular}

It is worth noting in relation to the mean percentage of women elected to the NOC executive committee only Africa has a mean which exceeds the IOC minimum target of $20 \%$ of the membership of such committees being female.. 


\section{Group 3: Indicators of Female Involvement in National Politics}

The success of women in NOC elections may be compared also with the data from the United Nations for female electoral success in national politics. A one way between groups analysis of variance with planned comparisons was conducted to compare the impact of Huntington groups on (a) percentage of women in the Lower or single House of Parliament for all nations; (b) percentage of women in ministerial positions; (c) percentage of women in the Upper House. The planned comparison was of Islamic and other groups. There was a significant difference in the contrast tests for both (a) and (b). For the percentage of women in the Lower House there was a significant difference between the mean for Islamic groups and others $F(1,97)=$ $3.93, p=0.05$. For the percentage of women ministers $F(1,36)=7.3, p=.01$ there was also a significant difference between Islamic and other groups. In both cases means for Asian other are slightly lower than the Islamic group, while means of other groups are significantly higher.

The fact that the Lower House electoral outcomes and ministerial positions achieved by women in Islamic countries is significantly lower than that for all but one of the Huntington groups, while in NOC elections and positions this is not the case suggests that in terms of gender equity in general electoral outcomes what progress has been made across all countries, while unsatisfactory generally, is more markedly so in the Islamic and Asian Other groups. While in the elections for NOC Executives the Islamic group sits in the mid-range in terms of mean percentage of female members of NOC Executives, its mean being not significantly lower than that of other groups. In other words women are disadvantaged in terms of membership of the Lower House and in terms of access to ministerial positions as well in terms of membership of NOC Executives but in the case of the first two of these, Islamic groups are generally more disadvantaged. 
Table 5. General political representation by women across Huntington types

\begin{tabular}{|c|c|c|c|c|c|}
\hline & & $\mathbf{N}$ & Mean & $\begin{array}{r}\text { Std. } \\
\text { Deviation } \\
\end{array}$ & Std. Error \\
\hline \multirow{7}{*}{$\begin{array}{l}\% \text { of women } \\
\text { in Lower or } \\
\text { single House } \\
\text { of Parliament }\end{array}$} & Western & 41 & 20.268 & 12.9785 & 2.0269 \\
\hline & Orthodox & 8 & 17.100 & 8.2124 & 2.9035 \\
\hline & Islamic & 19 & 11.421 & 7.9641 & 1.8271 \\
\hline & African & 16 & 22.269 & 14.0325 & 3.5081 \\
\hline & $\begin{array}{l}\text { Latin } \\
\text { American }\end{array}$ & 14 & 18.414 & 12.7156 & 3.3984 \\
\hline & Asian Other & 5 & 10.580 & 7.6920 & 3.4400 \\
\hline & All NOCs & 103 & 17.979 & 12.2285 & 1.2049 \\
\hline \multirow{7}{*}{$\begin{array}{l}\% \text { of women } \\
\text { in Ministerial } \\
\text { Positions }\end{array}$} & Western & 40 & 24.455 & 14.7355 & 2.3299 \\
\hline & Orthodox & 8 & 12.013 & 9.8405 & 3.4791 \\
\hline & Islamic & 18 & 10.400 & 7.1764 & 1.6915 \\
\hline & African & 16 & 19.906 & 8.7656 & 2.1914 \\
\hline & $\begin{array}{l}\text { Latin } \\
\text { American }\end{array}$ & 14 & 18.100 & 13.6305 & 3.6429 \\
\hline & Asian Other & 5 & 5.960 & 4.2383 & 1.8954 \\
\hline & All NOCs & 101 & 18.448 & 13.1975 & 1.3132 \\
\hline \multirow{7}{*}{$\begin{array}{l}\% \text { of women } \\
\text { in Upper } \\
\text { House of } \\
\text { Parliament or } \\
\text { Senate }\end{array}$} & Western & 14 & 23.329 & 10.9224 & 2.9191 \\
\hline & Orthodox & 2 & 18.750 & 19.8697 & 14.0500 \\
\hline & Islamic & 9 & 18.900 & 11.6339 & 3.8780 \\
\hline & African & 7 & 25.671 & 7.7304 & 2.9218 \\
\hline & $\begin{array}{l}\text { Latin } \\
\text { American }\end{array}$ & 10 & 22.380 & 12.8641 & 4.0680 \\
\hline & Asian Other & 2 & 20.700 & 4.6669 & 3.3000 \\
\hline & All NOCs & 44 & 22.252 & 10.9192 & 1.6461 \\
\hline
\end{tabular}




\section{Group 4: Professional Roles Played by Women in the NOC}

While groups 1 to 3 above focus on the political domain, elected positions for women, this group seeks to identify differences between Islamic countries and other Huntington groups in terms of the professional roles played by women. Thus a one way between groups analysis of variance with planned comparisons was conducted to compare the impact of Huntington groups on (a) the percentage of full time workforce in the NOC which is female; and (b) the percentage of part-time work force which is female. Only the former proved to be significant at the $p<.05$ level, $F(1,98)=10.3, p=.00$.

Female participation in the workforce of course reveals only part of the picture since this data does not reveal in what capacities women work and at what level. Horizontal segregation within NOCs may confine women to certain types of role. From our interview data for example it seems clear that significant numbers of female NOC employees work in the area of translation / interpretation. Vertical segregation may also mean that women are absent from senior management roles.

\section{Group 5 Indicators of Democratic Health of the NOC Electoral System}

The level of electoral competition was evaluated by constructing a scale consisting of four items: Presence of more than one candidate for the most recent elections to the following positions - president, secretary general, treasurer and other executive board positions. The Cronbach alpha value for the scale was .709. There was not a significant difference between the Islamic and other groups in terms of electoral competition within the NOC.

An indicator of good political governance, the appointment of independent election scrutineers was also adopted as a measure of a healthy democratic system. In relation to the question of independent scrutiny of elections there was virtually no absolute difference (and certainly no statistically significant difference) between NOCs in the Islamic group (53\%) and others (49\%) who had appointed formal scrutineers.

\section{Group 6: Existence of a Formal Statement of Gender Equity Policy}

The final group of indicators relates to the level of activity in relation to gender equity policy within the NOC. A scale was constructed from three items, (a) whether the NOC had a Woman in Sport Commission (or equivalent); (b) whether it had adopted a formal policy in relation to gender equity; and (c) whether the NOC had formal performance measures related to gender equity. A Cronbach's alpha of .655 was obtained for this scale. This was improved to the level of .796 by excluding item (a). Thus a one way between groups analysis of variance with planned comparisons was conducted to compare the impact of Huntington groups on the two item scale level of activity in relation to gender equity. The ANOVA identified significant differences between the means for the Islamic and other groups $F(1,25)=13.75, p=.001$. This result was a direct reflection of the significantly greater level of formal activity on gender equity in the NOCs of the Islamic group (see Figure 2). 
Figure 2. Means of gender equity scale for different Huntington cultural groupings of countries.

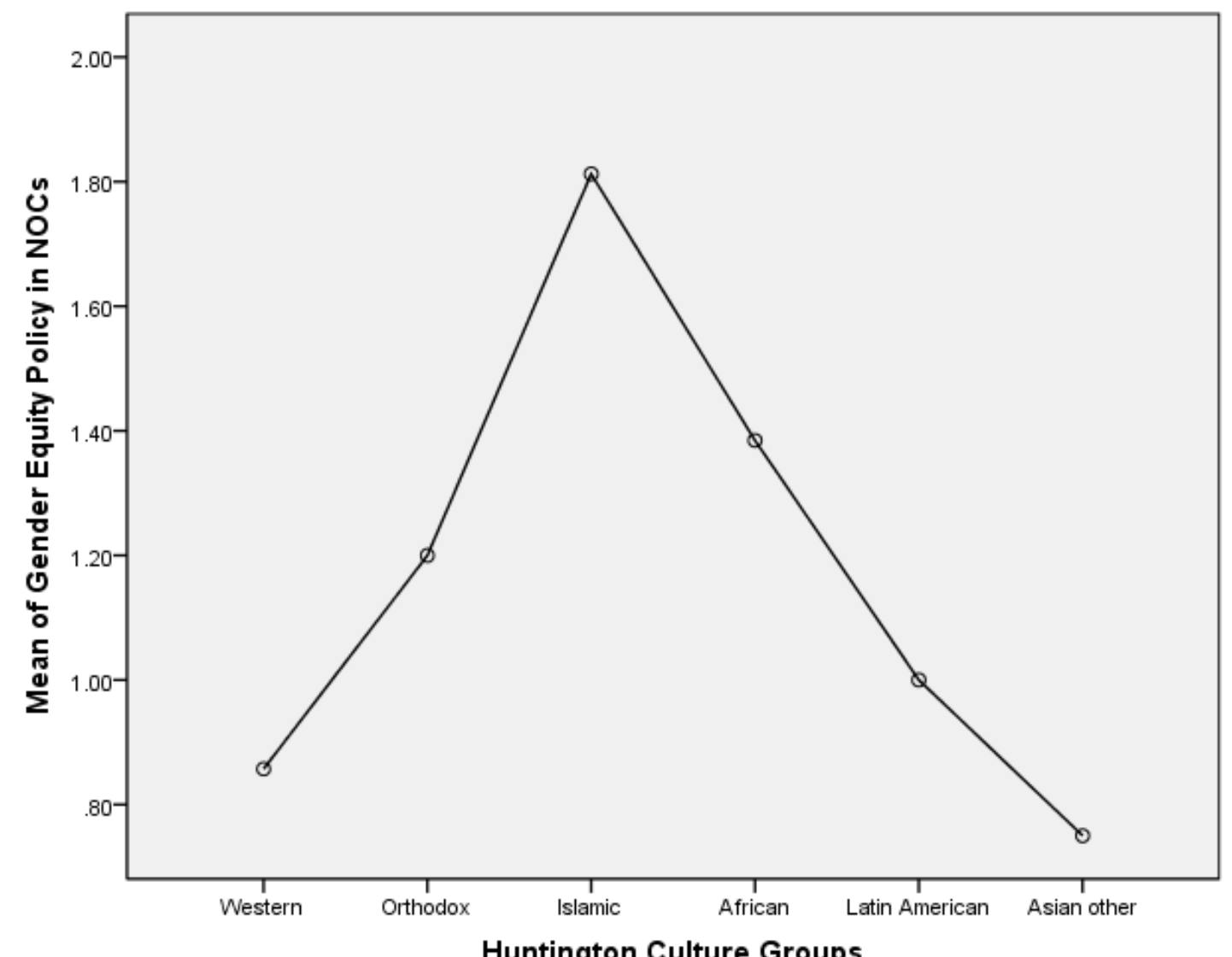

Huntington Culture Groups

This finding undermines the notion of resistance to embracing the gender equity message at least at the formal level by NOCs in Muslim majority countries. In formally adopting both gender equity policy and in adopting gender equity performance measures these countries are providing evidence of engaging with the question of how to achieve equity. Of course this is a measure which reflects what the NOCs proclaim they will do rather than measuring what they actually do in respect of gender equity but the data is nevertheless striking. It may be that Islamic countries have found themselves under pressure within the Olympic movement to conform while equally conservative elements in other Huntington groups do not find themselves so readily exposed to public scrutiny or criticism.

\section{Conclusions}

As Guttmann has argued the emergence of modern sport is bound up with the emergence of modernity in terms of its rational, bureaucratic, 'scientistic' character. The West in the discourse of modernity is implicitly taken as the 'master signifier' which thus defines the meaning and values of modern sport in western terms. Those meanings and value systems were constructed in opposition to traditional and 'indigenous' sports practices. In terms of sport history, sport has thus been studied from the perspective of the West, with an implicitly dominant (paternalist) ideology of a "civilisational mission", and such paternalism is in line with the Huntingtonian philosophy which distinguishes the West from the 'rest'. The history of acceptance of modern sport practice by non-western native (colonised) populations, is largely a history of deculturation, the loss of traditional (defined as 'barbaric', 'superstitious') sport practices, and was explained by western historians and anthropologists as a sign of 'assimilation' of (western) modernist values, and thus, of the western universalism. An example of this de-culturation through sport was the 'imposition' of women's participation in the Soviet communist empire in Muslim societies, to combat socalled 'religious prejudice' and 'reactionary tradition' (Riordan, 1999). However, our data calls into question this implicit notion of the cultural superiority of the West, since sport as a site of modernity in 
terms of the place accorded to women in its governance, provides an example of how Muslim societies are in some senses taking at least as seriously as their western counterparts if not more, the need to address women's participation in decision making. It is not that Muslim majority societies are a beacon of 'progressive practice' in this respect, it is that Muslim majority countries are certainly no worse and in some senses performing better against measures of female inclusion in decision making within NOCs than the West.

The failure to engage women in decision making positions in the West is explained by reference to patriarchal forces within western societies. Our data however reinforces the need in respect of Muslim majority societies to look beyond the focus on Islam as the source of women's disadvantage in Muslim majority countries and instead to look to patriarchal forms of dominance in such societies. As Muslim feminists have argued the dominance of male voices in interpreting religious authority, and in the defining of ijtihad (religious reasoning) is a source of disadvantage for women to be challenged . We thus concur with Mandaville who concludes that this 'religion blaming' strategy of seeing Islam as the problem rather than some male interpretations of 'the' Islamic way of life is simply mistaken.

"Islam often offers the easy way out, both for analysts seeking a quick explanation and for the policy-makers of the societies in question who want to sidestep the structural causes of gender inequality and mistreatment of women by referring to 'cultural' causes which are 'conveniently out of their hands'" .

\section{Notes}

[1] Laine, 'Gender equality and the 2012 Olympic Games [Online]'. Helsinki: International Working Group on Women and Sport. Available: http://www.iwg-gti.org/catalyst/july2012/gender-equality-and-the-2012-oly/ (Accessed 2012.08.07 2012)

[2] IOC, 'Factsheet: The Programme of the Games of the Olympiad - Update'

[3] Amara, 'Veiled Women Athletes in the 2008 Beijing Olympics: Media Accounts.'

[4] Shergold, 'The Muslim women who overcame the odds and the prejudice to make history today on the Olympic stage' [Online]. Available: http://www.dailymail.co.uk/news/article2183262/Olympics-2012-The-Muslim-women-overcame-odds-make-London.html (Accessed 2012.08.03)

\section{References}

Afshar, Haleh. Islam and Feminisms : An Iranian Case-Study, Women's Studies at York Series. New York: St. Martin's Press, 1998.

Akbar S. Ahmed. Postmodernism and Islam. London: Routledge, 1992.

Amara, M, and I Henry. "Deconstructing the Debate around Sport and the 'Question' of 'Muslim Minorities' in the West." In Islam in the West: Key Issues in Multiculturalism, edited by M Farra, S Robinson, Y Valli and P Wetherly. Basingstoke: Palgrave, 2012.

Amara, Mahfoud. "Veiled Women Athletes in the 2008 Beijing Olympics: Media Accounts." The International Journal of the History of Sport 29, no. 4 (2012): 638-51.

Bulliet, Richard The Case for Islamo-Christian Civilisation New York: Columbia University, 2004. 
Fernea, E W. "In Search of Islamic Feminism: One Woman's Global Journey." Anchor Books.

Guttmann, A. From Ritual to Record. New York: Columbia University Press, 1978.

Haddad, Y, and J Esposito, eds. Islam, Gender and Social Change. Oxford: Oxford University Press, 1998.

Henry, I. "Bridging Research Traditions and World Views: Universalisation Versus Generalisation in the Case for Gender Equity." In Transnational and Comparative Research in Sport: Globalisation, Governance and Sport Policy, edited by I Henry and Institute of Sport and Leisure Policy. London: Routledge, 2007.

Henry, I, and L Robinson. "Gender Equity and Leadership in Olympic Bodies: Women, Leadership and the Olympic Movement 2010." 93. Lausanne: International Olympic Committee \& Centre for Olympic Studies \& Research, Loughborough University, 2010.

Henry, I.P., W. Radzi, E. Rich, E. Theodoraki, and A. White. Women, Leadership, and the Olympic Movement. Loughborough: Institute of Sport \& Leisure Policy, Loughborough University and I.O.C, 2004.

Huntington, S.P. The Clash of Civilizations and the Remaking of World Order: Simon \& Schuster, 1997.

IOC. "Factsheet: The Programme of the Games of the Olympiad - Update ", 2012.

Karam, Azza M. Women in Parliament : Beyond Numbers. Stockholm, Sweden: International IDEA, 1998.

Karam, Azza M. Women, Islamisms and the State: Contemporary Feminisms in Egypt. Basingstoke: Palgrave, 1998.

Laine, K. "Gender Equality and the 2012 Olympic Games." International Working Group on Women and Sport, http://www.iwg-gti.org/catalyst/july-2012/gender-equality-and-the-2012-oly/.

Malik, I H. Islam and Modernity. London: Pluto Press, 2004.

Mandaville, P. . Transnational Muslim Politics, Research in Transnationalism. London: Routledge 2003.

Mernissi, F, and M Lakeland. The Veil and the Male Elite : A Feminist Interpretation of Women's Rights in Islam. Reading, Mass ; Wokingham: Addison-Wesley, 1991.

Said, E. Orientalism :Western Conceptions of the Orient. London: Penguin, 1991.

Said, Edward W. Culture and Imperialism. Vintage Books ed. New York: Vintage Books, 1994.

Salter, M. "The Clash of Civilisations and the War on Terror(Ists): An Imperialist Discourse." GLOBAL DIALOGUE 5, no. 1-2 (2003): On line http://www.worlddialogue.org/content.php?id=222.

Shergold, A. "The Muslim Women Who Overcame the Odds and the Prejudice to Make History Today on the Olympic Stage." MailOnline, http://www.dailymail.co.uk/news/article-2183262/Olympics-2012The-Muslim-women-overcame-odds-make-London.html.

Tibi, Bassam. Islam between Culture and Politics. Houndmills, Basingstoke, Hampshire ; New York: Palgrave, 2001.

United Nations. "Women in Politics: 2010 - Situation on 1 January 2010." In United Nation - women watch. Brailly: The Inter-Parliamentary Union and the United Nations Division for the Advancement of Women, 2010. 
